\title{
Peningkatan Produksi Susu dan Income Over Feed Cost (IOFC) Kambing Perah dengan Penambahan Katuk (Sauropus adrogunus) dan Kunyit (Curcuma longa) pada Sakura Blok
}

\author{
Increased Milk Production and Income Over Feed Cost (IOFC) Dairy Goats With Addition of \\ Katuk (Sauropus adrogunus) and Kunyit (Curcuma longa) to Sakura Blok
}

\author{
Jarmuji, D. Suherman, E. Silvia dan I. Apriyani
}

Fakultas Pertanian Universitas Bengkulu

JL.W.R.Supratman, Bengkulu 38126

email: jarmuji_78@yahoo.com

\begin{abstract}
ABTRACT
The demonstration plot was carried out for 40 days using the Latin square method with 4 treatments and four replications (Gasperz, 1991). Each treatment period is carried out for 10 days (4 days adaptatif periode, 6 days data collection). The Demonstration plot etc: D1(sakura block), D2 (Sakura block $+2 \%$ katu and 2\% Tumeric, D3 (sakura block+4\% tumeric)and D4 (sakura block+4\% katu). The dairy goat used was the Peranakan Etawa (PE), demplot as much as 4 tails with an average weight of $50 \mathrm{~kg}$, each goat was fed in the form of fresh Forage ((4 kg Indigofera $s p$ : $1 \mathrm{~kg}$ Brachiaria decumben), tofu $4 \mathrm{~kg}$ (recommendations from farmers in LPPB). Sakura block is given as much as $150 \mathrm{~g} /$ head / d. The results of the demonstration plot showed that the highest milk production was produced at D4 which was 2,664.4 $\mathrm{ml} /$ head / day followed by D2 (2,622.7 $\mathrm{ml} / \mathrm{ek} / \mathrm{day}), \mathrm{D} 3$ $(2,456,2 \mathrm{ml} / \mathrm{ekd} / \mathrm{d})$ and D1 (2,425 $\mathrm{ml} /$ head /day). Although the ration costs incurred in D4 were the highest among the demonstration plots, the Income Over Feed Cost (IOFC) obtained was also relatively high at Rp. 60,354 / head / day. While IOFC D1, D2 and D3 were obtained Rp. 54,859 , Rp59,494 and Rp55,484
\end{abstract}

Key word : dairy goat, milk production, sakura block, IOFC

\begin{abstract}
ABSTRAK
Demplot dilaksanakan selama 40 hari menggunakan rancangan bujur sangkar latin dengan 4 perlakuan dan 4 ulangan (Gasperz, 1991). Masing-masing perlakuan dilaksanakan selama 10 hari (4 hari periode adaptasi dan 6 hari periode koleksi data). Perlakuan yang dilakukan di dalam Demplot (D) antara lain: D1(sakura blok), D2 (sakura blok +25 katu $+2 \%$ kunyit), D3 (sakura blok $+4 \%$ kunyit) dan D4 (sakura blok + 4\% katu). Kambing perah yang digunakan dalam demplot adalah bengsa kambing Peranakan Etawa (PE) dengan berat rata-rata 50 $\mathrm{kg}$, Pakan yang diberikan pada masing-masing perlakuan berupa hijauan (4 kg Indigofera sp: $1 \mathrm{~kg}$ Brachiaria decumbens), dan $4 \mathrm{~kg}$ ampas tahu (rekomendasi dari LPPB Pondok Kubang). Sakura blok diberikan sebanyak 150 gram/ekor/hari pada masing-masing kambing.hasil demplot menunjukan bahwa produksi susu tertinggi pada D4 yaitu sebesar 2.664,4 ml/ek/hari diikuti oleh D2 (2,622.7 ml / ek / hari), D3 (2,456,2 ml / ek/ hari) and D1 $(2,425 \mathrm{ml} / \mathrm{ek} / \mathrm{hari})$. Meskipun biaya ransum yang dikeluarkan pada D4 relatif paling tinggi diantara kelompok demplot, namun Income Over Feed Cost (IOFC) yang diperoleh juga relatif tinggi yaitu sebesar Rp,60.354/ekor/hari.sementara D1, D2 dan D3 IOFC yang diperoleh sebesar Rp54.859, Rp59.494 dan Rp55.484
\end{abstract}

Kata kunci : kambing perah, produksi susu, sakura blok, IOFC

\section{PENDAHULUAN}

Peternakan Kambing perah merupakan salah satu sektor usaha peternakan yang banyak memberi manfaat dalam memenuhi kebutuhan pangan yang terus meningkat dan penciptaan lapangan kerja. Ternak kambing memiliki peranan yang sangat penting dalam komponen usaha tani di Indonesia. Kambing berfungsi sebagai ternak penghasil daging, susu, kulit dan bulu serta kotoran (Devendra dan Burns, 1994). Menurut Sudono dan Abdulgani (2002), kambing tersebar luas di daerah tropis dan subtropis, karena memiliki sifat toleransi 
yang tinggi terhadap hijauan pakan ternak, rerumputan dan dedaunan serta mampu memanfaatkan bermacam- macam hijauan yang tidak dapat dimakan oleh ternak ruminansia lainnya seperti domba dan sapi. Kambing juga mempunyai kemampuan beradaptasi yang luas terhadap berbagai keadaan lingkungan. Kambing perah juga memiliki siklus reproduksi yang cepat. Atabany (2013) menyatakan kambing Peranakan Etawa dikawinkan pertama kali umur 10-12 bulan dengan bobot $30-40 \mathrm{~kg}$, angka kawin perkebuntingan $1,14 \pm 0,46$ kali. Rata-rata masa kosong induk kambing PE adalah 93,9 $\pm 15,5$ hari (Rara et al., 2011), sedangkan menurut Murtidjo (1993) normalnya masa kosong adalah 60 - 90 hari. Masa kosong adalah masa dimana ternak kambing tidak dalam kondisi bunting. Coosly (1984), menyatakan bahwa selang beranak kambing di daerah tropis pada kondisi makanan dan tatalaksana yang baik antara 260 sampai dengan 290 hari. Pada kambing PE selang beranak sekitar 269 hari (Setiadi dan Sitorus, 1983). Induk kambing dianggap produktivitas tinggi apabila dapat menghasilkan keturunan yang banyak atau lebih dari satu ekor per kelahirannya (Davendra dan Burns, 1994).

Kambing Peranakan Etawa (PE) merupakan salah satu dari tujuh kambing lokal yang telah dikarakterisasi guna mengeksplorasi potensi keragaman genetiknya untuk dimanfaatkan sebagai sumber peningkatan mutu genetik kambing di Indonesia. Kambing PE termasuk tipe dwiguna, pertumbuhannya relatif lambat dengan produksi susu sekitar 1,5 - 2 liter per hari (Batubara, 2007). Karakteristik kambing PE adalah kuping menggantung ke bawah dengan panjang 18-19 cm, tinggi badan antara 75-100 cm, bobot jantan sekitar $40 \mathrm{~kg}$ dan betina sekitar $35 \mathrm{~kg}$. Pakan kualitas baik bobot ternak dapat mencapai $80 \mathrm{~kg}$.Kambing PE jantan berbulu di bagian atas dan bawah leher, rambut pundak dan paha belakang lebih lebat dan panjang.Kambing PE betina memiliki rambut panjang hanya pada bagian paha belakang.Warna rambut kambing PE terdiri atas kombinasi coklat sampai hitam atau abu-abu dan muka cembung (Hardjosubroto, 1994).Ciri khas dari kambing Peranakan Etawah adalah pada bentuk mukanya yang cembung, bertelinga panjang yang mengglambir, postur tubuh tinggi.

Lembaga Pengembangan Pertanian Babtis (LPPB) Pondok Kubang adalah satu satunya lembaga di Propinsi Bengkulu yang sampai saat ini konsisten mengembangkan kambing perah dengan cara bermitra dengan masyarakat. Pola pengembangan ternak kambing perah yang diterapkan adalah dimana LPPB menyediakan bibit unggul kambing perah untuk dikembangkan ke masyarakat dengan pola gaduan. Kelompok masyarakat yang akan dipilih sebagai penggaduh sebelumnya diberi pengetahuan dan keterampilan bagaimana beternak kambing perah dengan cara magang di LPPB selama beberapa hari.

Namun demikian, pengembangan kambing perah di Bengkulu baik di LPPB maupun di masyarakat (gaduan) mengalami permasalahan pada sisi produksi. Populasi kambing perah di LPPB Pondok Kubang saat ini sebanyak 60 ekor, sebanyak $75 \%$ populasi dipertahankan laktasi dengan rata-rata produksi susu 1-3 liter/ekor/hari sedangkan Kambing yang dipelihara di masyarakat (gaduan) produksinya hanya 0.2-0.5 liter/ekor/hari. Produksi susu yang rendah ini tentu dapat merugikan peternak kambing. Produksi susu dipengaruhi oleh mutu genetik, umur induk, ukuran dimensi ambing, bobot hidup, lama laktasi, tatalaksana yang diberlakukan terhadap ternak (perkandangan, pakan dan kesehatan), kondisi iklim, daya adaptasi ternak dan aktivitas pemerahan (Phalepi, 2004). Menurut Novita et al. (2006), produksi susu pada kambing PE dapat berkisar antara 567,1 gram/ekor/hari, hingga 863 gram/ekor/hari. Menurut Agus (1997), peningkatan produksi susu dapat dilakukan dengan cara memperbaiki manajemen pakan. Cara ini dianggap paling mudah dilakukan dibanding seleksi, karena memperbaiki manajeman pakan dapat dilakukan dengan cara memperbaiki kandungan nutrisi pakan. Selain itu 
perbaikan manajemen pakan memiliki pengaruh lebih cepat terhadap produksi dan kualitas susu dibanding perbaikan dengan cara seleksi.

Sakura blok adalah pakan suplemen yang terdiri dari campuran bahan bahan yang mudah diperoleh di pedesaan seperti gula merah, dedak, jagung giling, sagu, urea, garam dapur, TSP, lakta mineral dan top mix.

Penambahan tepung katuk dan tepung kunyit pada pada kambing perah yang diberi pakan suplemen sakura blok dapat meningkatkan produksi dan kualitas susu. Tanaman katuk mengandung beberapa senyawa kimia, antara lain alkaloid papaverin, protein, lemak,vitamin, mineral, saponin, flavonid dan tanin.Beberapa senyawa kimia yang terdapat dalam

tanaman katuk diketahui berkhasiat obat (Rukmana, 2003). Flavonoid pada daun katu (Sauropus androgonus) memiliki sifat antioksidan yang kuat (Zuhra et al., 2008). Kunyit memiliki aktivitas antioksidan yang cukup tinggi dan senyawa kurkumin merupakan komponen utama yang menyebabkan aktivitas antioksidan tersebut (Chattophadyay et al., 2004). Menurut Tasripin (2009) pemberian ransum berimbuhan kunyit, $\mathrm{Zn}$ proteinat, dan $\mathrm{Cu}$ proteinat menurunkan status mastitis. Pemberian pakan imbuhan Kunyit, Zn proteinat, dan $\mathrm{Cu}$ proteinat memberikan hasil terbaik menurunkan mastitis subklinis. Kunyit mengandung zat kurkumin yang berfungsi dalam pemutusan rangkaian radikal bebas (Sidik dan Muhtadi, 1992). Berdasarkan uraian diatas maka perlu dilakukan demplot untuk menguji seberapa besar pengaruh tepung kunyit dan tepung daun katuk yang ditambahkan pada pakan suplemen sakura blok terhadap produksi susu kambing PE di LPPB Pondok Kubang

\section{MATERI DAN METODE}

Demplot dilakukan selama 40 hari di Lembaga Pengembangan Pertanian Babtis (LPPB) Pondok Kubang. Kandang yang digunakan untuk demplot yaitu kandang individu ukuran $1,2 \mathrm{~m} \times 1,5 \mathrm{~m}$ yang sudah tersedia di LPPB. Kambing perah yang digunakan adalah jenis kambing PE laktasi dengan berat badan rata-rata $50 \mathrm{~kg}$. Kandang yang digunakan adalah kandang permanen dengan sistem terbuka, menggunakan atap seng dan lantai kayu Pakan yang diberikan berupa hijauan segar sebanyak $5 \mathrm{~kg} / \mathrm{ekor} / \mathrm{hari}$ yang terdiri dari leguminosa (Indigofera $s p$ ) sebanyak $4 \mathrm{~kg}$ dan rumput (Brachiaria sp) 1 $\mathrm{kg}$, ampas tahu sebanyak $4 \mathrm{~kg}$ dan pakan suplemen sakura blok sebanyak 0,15 $\mathrm{kg} / \mathrm{ekor} / \mathrm{hari}$ (hasil rekomendasi dari LPPB Pondok Kubang). Komposisi bahan-bahan penyusun sakura blok antara lain : $32 \%$ gula kelapa, $28 \%$ dedak padi, $15 \%$ sagu, $15 \%$ jagung giling, $5 \%$ urea, $1 \%$ TSP, $1 \%$ mineral mix dan 1\% top mix (Jarmuji et al. 2017)

Sakura blok dibuat dengan beberapa langkah, yaitu timbang seluruh bahan dan panaskan gulah merah hingga mendidih. Bahan -bahan yang lain dicampur dan diaduk hingga merata,Langkah selanjutnya cetak dengan menggunakan alat pencetak blok lalu bungkus dengan menggunakan plastik (wrap plastik). Selanjutnya pakan dapat disimpan atau langsung diberikan pada ternak. Pembuatan tepung kunyit dilakukan dengan cara mengupas kulit kunyit lalu dibersihkan, diiris kecil ukuran 1-2 cm lalu dijemur sampai kering. Selehak kering kunyit digiling menjadi tepung. Daun katu yang digunakan adalah daun katu yang sudah tua ataupun yang muda, pisahkan dari batang dan tangkai lalu dijemur sampai kering dan digiling menjadi tepung.

Demplot menggunakan 4 ekor kambing PE yang sedang laktasi, desain demplot menggunakan Rancangan Bujur Sangkar Latin (RBSL) dengan 4 uji lapang dan 4 periode sebagai ulangan, setiap periode 10 hari (4 hari periode adaptasi dan 6 hari pengukuran produksi susu). Untuk mendapatakan hasil data produksi susu yang akurat, maka perlu di desain pengujian pakan sakura blok, tepung kunyit dan tepung katuk dilapangan (demplot). Beberapa desain Demplot (D) dilapangan adalah sebagai berikut :

1. Kelompok Kambing PE yang mendapat pakan suplemen sakura blok sebanyak $150 \mathrm{gr} / \mathrm{ek} / \mathrm{h}(\mathrm{D} 1)$ 
2. Kelompok kambing PE yang mendapat pakan suplemen sakura blok $150 \mathrm{~g} / \mathrm{ek} / \mathrm{h}$ ditambah $2 \%$ Tepung Kunyit dan $2 \%$ Tepung katuk dari jumlah sakura blok (D2)

3. Kelompok kambing PE yang mendapat pakan suplemen sakura blok $150 \mathrm{~g} / \mathrm{ek} / \mathrm{h}$ dan $4 \%$ tepung kunyit dari jumlah sakura blok (D3)

4. Kelompok kambing PE yang mendapat pakan suplemen sakura blok $150 \mathrm{~g} / \mathrm{ek} / \mathrm{h}$ dan $4 \%$ tepung katuk dari jumlah sakura blok (D3).

Komposisi dan harga bahan bahan sakura blok disajikan pada tabel 1 .

Tabel 1. Komposisi dan harga satuan bahan bahan penyusun sakura blok

\begin{tabular}{lcrc}
\hline Bahan & Kg & $\begin{array}{c}\text { Harga } \\
\text { (Rupiah) }\end{array}$ & $\begin{array}{l}\text { Total } \\
\text { (Rupiah) }\end{array}$ \\
\hline Gula merah & 0,32 & 16.000 & 5.120 \\
Dedak & 0,28 & 2.000 & 560 \\
Sagu & 0,15 & 7.000 & 1.050 \\
Jagung giling & 0,15 & 6.000 & 900 \\
Urea & 0,05 & 4.000 & 200 \\
Garam dapur & 0,02 & 8.000 & 160 \\
TSP & 0,01 & 5.000 & 50 \\
Mineral Mix & 0,01 & 20.000 & 200 \\
Top mix & 0,01 & 20.000 & 200 \\
\hline Total harga & 1,00 & & 8.440 \\
\hline
\end{tabular}

Sumber : harga pasar di Kota bengkulu (2018)

Produksi susu diukur setiap hari pada pagi hari dan sore hari dengan melakukan pemerahan, yang kemudian diukur dengan menggunakan gelas ukur yang dinyatakan dalam satuan liter. Data yang dikumpulkan berupa data produksi susu dan harga susu serta harga ransum. Harga ransum kambing perah antara lain harga Indigofera (Rp $800 / \mathrm{kg}$ ), Brachiaria decumbens (Rp,500/kg), ampas tahu (Rp. 400.kg), sakura blok (Rp.8.440/kg), tepung kunyit (Rp. 25.000/kg) dan tepung katu (Rp. 80.000/kg) ( sumber: survei harga pasar kota Bengkulu). Data perhitungan ekonomi dianalisis dengan menggunakan perhitungan Income Over Feed Cost (IOFC) untuk mengetahui pendapatan yang diperoleh berdasarkan penjualaan susu dan pengeluaran biaya pakan. Hasil demplot disajikan dalam bentuk tabel statistik dan dibahas secara deskriptif

\section{HASIL DAN PEMBAHASAN}

\section{Produksi susu}

Hasil pengamatan terhadap kelompok kambing PE yang mendapat pakan suplemen sakura blok, kunyit dan katuk diperoleh rata-rata produksi susu 2.542 $\mathrm{ml} /$ hari dengan produksi minimum 1.287 $\mathrm{ml} / \mathrm{hari}$ dan produksi maksimum 3.562 $\mathrm{ml} /$ hari (Tabel 2). Hasil ini lebih tinggi dibanding dengan rataan produksi susu kambing PE awal laktasi di beri pakan 90\% hijauan dan $10 \%$ konsentrat yaitu sebesar $1.128,75 \mathrm{ml} /$ hari (Marwah et al., 2010). Menurut Noor (2005), produksi susu harian kambing PE berkisar antara $1.000 \mathrm{ml}$ sampai $1.500 \mathrm{ml}$ per hari. Tingginya produksi susu kambing PE di LPPB babtis disebabkan adanya pengaruh pakan, dimana rata-rata kambing PE dengan bobot badan $50 \mathrm{~kg}$ di LPPB Pondok kubang mendapat pakan berupa $4 \mathrm{~kg}$ legum (Indigofera $\mathrm{sp}$ ) dan $1 \mathrm{~kg}$ rumput (Brachiaria decumben), $4 \mathrm{~kg}$ ampas

Tabel 2. Rataan produksi susu kambing PE yang diberi pakan sauplemen sakura blok, tepung kunyit dan tepung katuk

\begin{tabular}{|c|c|c|c|c|c|c|c|c|}
\hline \multirow{2}{*}{ Demplot } & \multicolumn{4}{|c|}{ Produksi susu (ml) } & \multirow{2}{*}{ Rataan } & \multirow{2}{*}{ Mak } & \multirow{2}{*}{ Min } & \multirow{2}{*}{ Sdev } \\
\hline & 1 & 2 & 3 & 4 & & & & \\
\hline D1 & 2.583 & 2.892 & 3.317 & 908 & 2.425 & 3.317 & 908 & 1.055 \\
\hline D2 & 1.700 & 2.442 & 2.949 & 3.400 & 2.623 & 3.400 & 1.700 & 729 \\
\hline D3 & 2.950 & 3.667 & 1.133 & 2.075 & 2.456 & 3.667 & 1.133 & 1.096 \\
\hline D4 & 3.867 & 1.408 & 2.483 & 2.899 & 2.664 & 3.867 & 1.408 & 1.018 \\
\hline Rata-rata & 2.775 & 2.602 & 2.471 & 2.321 & 2.542 & 3.562 & 1.287 & 975 \\
\hline
\end{tabular}


tahu dan 150 gr sakura blok plus tepung katu dan tepung kunyit. Sakura blok merupakan pakan suplemen yang mengandung komposisi nutrisi $17.36 \%$ Protein kasar, $5.49 \%$ Serat Kasar, 3.36 Lemak kasar dan $50.79 \%$ BETN (Jarmuji et al., 2017). Pemberian sakura blok yang ditambahkan $2 \%$ tepung kunyit dan $2 \%$ tepung katu pada sapi perah sebanyak 400 gr/hari dapat meningkatkan produksi susu 2-3 liter/ekor/hari (Suherman et al., 2018).

Penambahan tepung katuk dan dan tepung kunyit dapat meningkatkan produksi susu kambing PE. Rata-rata produksi susu tertinggi kambing PE yang diberi tambahan $4 \%$ tepung katu yaitu sebesar $2.664 \mathrm{ml} / \mathrm{hari}$, diikuti kelompok kambing yang mendapat tambahan $2 \%$ tepung katu dan 2\% tepung kunyit sebesar $2.623 \mathrm{ml} / \mathrm{hari}$, kelompok kambing yang mendapat $4 \%$ tepung kunyit sebesar $2.456 \mathrm{ml} /$ hari. sedangkan yang hanya mendapat tambahan pakan suplemen sakura blok rata-rata produksi susu sebesar 2.425 $\mathrm{ml} /$ hari. Daun katuk di masyarakat indonesia sering kali dijadikan sebagai sayur yang dapat meningkatkan produksi ASI, hal ini di duga di dalam daun katu mengandung sterrol yang bersifat estrogenik (Pidada dan Rai, 1999). Tambahnya, steroid dan vitamin A berperan merangsang proliferasi epitel alveolus sehingga akan terbentuk alveolus yang baru, dengan demikian terjadi peningkatan jumlah alveolus dalam kelenjar ambing. Pemberian daun katuk sebesar $0,06 \%$ dari bobot badan pada kambing PE awal Laktasi mampu meningkatkan produksi susu sebesar $233 \mathrm{ml} / \mathrm{hari}$, namun meningkatkan kadar protein pada kolusterum (Marwah et al., 2010). Penambahan tepung kunyit $4 \%$ pada pakan suplemen sakura blok tidak mampu meningkatkan produksi susu secara signifikan, peningkatannya hanya 31 $\mathrm{ml} /$ hari. Pemberian tepung kunyit sebagai antibiotik alami pada pakan cenderung meningkatkan kualitas susu. Kunyit memiliki aktivitas antioksidan yang cukup tinggi dan senyawa kurkumin merupakan komponen utama yang menyebabkan aktivitas antioksidan tersebut (Chattophadyay et al., 2004). Menurut Tasripin (2009) pemberian ransum berimbuhan kunyit, $\mathrm{Zn}$ proteinat, dan $\mathrm{Cu}$ proteinat menurunkan status mastitis.

\section{Pendapatan usaha kambing peranakan etawa}

Pendapatan kambing perah sebagian besar diperoleh dari penjualan susu.Penjualan susu terkait produksi susu yang dan kualitas susu yang dihasilkan sehingga diperlukan berbagai upaya untuk meningkatkan produksi dan kualitas susu Pendapatan atas biaya pakan (IOFC) peternak kambing Peranakan Etawa (PE) dapat dihitung dengan cara mencari selisih antara nilai jual produksi susu yang dihasilkan dengan biaya ransum yang diberikan. Menurut Yusdjah (2005), Kontribusi biaya pakan terutama hijauan dan konsentrat dalam produksi setiap liter susu mencapai 62,5\% (Yusdjah, 2005). Sementara hasil penelitian Mudikdjo et al.(2001) dibutuhkan $32,41 \%$ biaya konsentrat untuk memproduksi setiap liter susu pada sapi perah.Tingginya biaya pakan ini akan berdampak pada pendapatan peternak. Pemberian suplemen Sakura blok, kunyit dan katuk dapat dilakukan untuk meningkatkan produksi susudan pendapatan atas biaya pakan (Tabel 3). Sakura blok mampu meningkatkan pertambahan berat badan pada kambing kacang sebesar $40 \%$ yang diberi pakan rumput setaria (Jarmuji, 2000) dan pada Sapi lokal Kaur yang diberi pakan pelepah sawit dan rumput setaria dengan penambahan pakan sakura blok sebanyak 250 gr/hari mampu meningkatkan bobot badan hingga 0,60 per hari (Jarmuji et al., 2017). Sementara katu dan kunyit dipercaya sebagai obat herbal untuk meningkatkan produksi dan kualitas susu sapi perah (Rukmana, 2003; Zuhra et al., 2008; Tasripin, 2009).

Hasil demplot menunjukkan bahwa jumlah dan komposisi ransum dapat mempengaruhi produksi susu kambing perah. Perbedaan formulasi ransum terutama menajemen pemberian katu dan kunyit pada pakan suplemen sakura blok juga berdampak pada pengeluaran biaya pakan dan pendapatan yang diterima dari penualan susu. 
Tabel 3. Pendapatan peternak berdasarkan jumlah ransum yang diberikan dan produksi susu

\begin{tabular}{|c|c|c|c|c|c|c|c|c|}
\hline \multirow{2}{*}{ Uraian } & \multicolumn{2}{|r|}{ D1 } & \multicolumn{2}{|r|}{ D2 } & \multicolumn{2}{|r|}{ D3 } & \multicolumn{2}{|r|}{ D4 } \\
\hline & Vol & Harga & Vol & Harga & Vol & Harga & Vol & Harga \\
\hline \multicolumn{9}{|l|}{ Biaya Ransum } \\
\hline Sakura blok (gr) & 150 & Rp 1.266 & 150 & Rp 1.266 & 150 & Rp 1.266 & 150 & Rp 1.266 \\
\hline Katuk (gr) & 0 & $\mathrm{Rp} 0$ & 3 & $\operatorname{Rp} 240$ & 0 & $\operatorname{Rp} 0$ & 6 & Rp 480 \\
\hline Kunyit (gr) & 0 & $\operatorname{Rp} 0$ & 3 & $\operatorname{Rp} 75$ & 6 & $\operatorname{Rp} 150$ & 0 & $\operatorname{Rp} 0$ \\
\hline $\begin{array}{l}\text { Indigofera } s p(\mathrm{~kg}) \\
\text { Brachiaria }\end{array}$ & 4 & $\mathrm{Rp} 2.400$ & 4 & $\operatorname{Rp} 2.400$ & 4 & $\operatorname{Rp} 2.400$ & 4 & Rp 2.400 \\
\hline decumbens ( $k g$ ) & 1 & Rp 500 & 1 & Rp 500 & 1 & Rp 500 & 1 & Rp 500 \\
\hline Ampas tahu(kg) & 4 & $\mathrm{Rp} 1.600$ & 4 & $\mathrm{Rp} 1.600$ & 4 & $\mathrm{Rp} 1.600$ & 4 & Rp 1.600 \\
\hline Total & & Rp 5.766 & & Rp 6.081 & & Rp 5.916 & & Rp 6.246 \\
\hline \multicolumn{9}{|l|}{ Pendapatan } \\
\hline Produksi susu (l) & 2,425 & $\operatorname{Rp} 60.625$ & 2,623 & $\operatorname{Rp} 65.575$ & 2,46 & $\operatorname{Rp} 61.400$ & 2,66 & $\operatorname{Rp} 66.600$ \\
\hline IOFC & & Rp 54.859 & & Rp 59.494 & $\mathrm{Rp} 2$ & Rp 55.484 & & $\mathrm{Rp} 60.354$ \\
\hline
\end{tabular}

Rata-rata harga susu kambing saat ini di kota bengkulu sebesar Rp. 25.000. liter, harga susu kambing di kota bengkulu saat ini belum memperhatikan tingkat kulaitas terutama kandungan nutrisi susu. Rata- rata biaya pakan yang dikeluarkan perhari selama demplot diperoleh nilai terendah sampai tertinggi sebagai berikut D1 (Rp, 5.766), D3 (Rp. 5.916), D2 (Rp. 6.081) dan D4 (Rp. 6,246). Perbedaan biaya pakan diantar kelompok kambing disebabkan oleh perbedaan formula penambahan katu dan kunyit padapakan suplemen sakura blok. Meskipun demikian, biaya pakan perhari yang dikeluarkan D4 paling tinggi diantara kelompok kambing yang lain tetapi IOFC yang diperoleh juga paling tinggi yaitu sebesar Rp.60.354, sementara IOFC pada D1, D2 dan D3 adalah Rp54.859, Rp59.494 dan Rp55.484. Perbedaan biaya atas pakan (IOFC) disebabkan oleh produksi susu kambing yang berbeda antar kelompok kambing (Tabel 3).

\section{KESIMPULAN}

Penambahan katu dan kunyit pada pakan suplemen sakura blok dapat meningkatkan produksi susu dan Income Over Feed Cost (IOFC) pada kambing PE. Peningkatan produksi susu tertinggi pada kelompok kambing PE yang mendapat tambahan tepung katu $4 \%$, diikuti dengan penambahan $2 \%$ tepung katuk dan $2 \%$ tepung kunyit pada pakan suplemen sakura blok. Disarankan untuk dihitung lebih lanjut analisis ekonomi penggunaan sakura blok yang ditambah kunyit dan katu dalam meningkatkan produksi susu kambing perah.meskipun biaya pakan yang dikeluarkan pada kelompok kambing yang diberi tambahan katu 4\% (D4) relatif paling tinggi diantara yang lain, namun IOFC yang diperoleh juga relatif paling tinggi yaitu sebesar Rp,60.354/ekor/hari.

\section{UCAPAN TERIMA KASIH}

Terima kasih kami sampaikan kepada Direktorat Jenderal Penguatan Riset dan Pengembangan, Kementrian Riset, Teknologi dan Pendidikan Tinggi nomor SP DIPA042.06.1.401516/2018. Tanggal 05 Desember 2017.

\section{DAFTAR PUSTAKA}

Agus, A. 1997. Pengaruh tipe konsentrat sumber energi dalam ransum sapi perah berproduksi tinggi terhadap 
produksi dan komposisi susu. Buletin

Peternakan. 21 (1):17-44

Atabany, A. 2013. Beternak Kambing Peranakan Etawah.Cetakan 1. PT Penerbit IPB Press. Kampus IPB Taman Kencana Bogor. Bogor. Indonesia.

Batubara, A. 2007. Tujuh Plasma Nutfah Kambing Lokal Indonesia. Artikel. Sinar Tani Edisi 25 April - 1 Mei 2007.

Chattopadhyay, I., K. Biswas, U. Bandyopadhyay, dan R. K. Banerjee. 2004. Turmeric and curcumin: Biological actions and medicinal applications. CURRENT SCIENCEBANGALORE. 87, 44-53.

Coosly, J. K. 1984. Role in Meeting Supplies. In Extention Goat Handbook. Printed and Distributed in Cooperation with the Extention Service. United State Department of Agriculture. Washington D.C. 587589.

Devendra, C. dan Mc. Burns. 1994. Produksi Kambing di Daerah Tropis. Institut Teknologi Bandung.

Hardjosubroto, W. 1994. Aplikasi Pemuliabiakan Ternak di Lapangan. Gramedia Widiasarana. Jakarta

Jarmuji. 2000. Pengaruh suplementasi sakura block terhadap pertambahan berat badan, konsumsi bahan kering dan efisiensi pakan pada Kambing Lokal. Skripsi. Jurusan Peternakan Fakultas Pertanian Universitas Bengkulu

Jarmuji, U. Santoso and B. Brata. 2017. The Effect of Palm Oil Fronds as Setaria Substitution Plus Sakura Block on Performance and Nutrient Digestibilies in Kaur Cattles. Pak. J. Nutr., 16:200-206

Marwah, M. P, Y.Y. Suranindyah, dan T. W. Murti. 2010. Produksi dan komposisi susu kambing Peranakan Etawa yang diberi suplemen daun katuk (Sauropus androgynus (L.) Merr) pada awala masa laktasi. Buletin Peternakan.34(2): 94-102.

Mudikdjo, K., U. Sehabuddin dan R. Pambudi. 2001. Analisis ekonomi usaha sapi perah di wilayah Propinsi Jawa Barat. Media Peternakan. Edisi Khusus 24: 57-66.

Murtidjo, B. A. 1993. Memelihara Kambing Sebagai Ternak Potong dan Ternak Perah. Penerbit Kanisius. Yogyakarta

Noor, H. 2005. Pengaruh pemberian pakan ubi kayu terhadap produksi susu kambing Peranakan Ettawa di Daerah Girimulyo, Kulonprogo. Skripsi. Fakultas Peternakan. Universitas Gadjah Mada. Yogyakarta.

Novita, C. I., A. Sudono, I. K. Sutama, dan T. Toharmat. 2006. Produktivitas kambing Peranakan Etawa yang diberi ransum berbasis jerami padi fermentasi. Media Peternakan. 29(2): 96-106.

Phalepi, M. A. 2004. Performa kambing Peranakan Etawah (studi kasus di peternak Pusat Pelatihan Pertanian dan Swadaya Pedesaan Citarasa). Skripsi. Fakultas Peternakan. Institut Pertanian Bogor, Bogor.

Pidada, I. B. R. 2002. Perbandingan infus daun katu dan daun lampes terhadap peningkatan berat badan anak dan jumlah alveolus kelenjar ambing pada mencit. Laporan Penelitian. Universitas Airlangga. Surabaya.

Rara, Wenny, S, Suyadi dan M, Nasich. 2011. Penampilan Reproduksi Induk dan Produksi Anak Lepas Sapih Kambing Peranakan Ettawa (PE) di Peternakan Rakyat Kecamatan Senduro Kabupaten Lumajang. Jurnal. Universitas Brawijaya. Malang. 
Rukmana, R. dan M. H. Indra. 2003. Katuk. Potensi dan Manfaatnya. Kanisius. Yogyakarta.

Suherman, D., Jarmuji dan A. H. K. Amrullah. 2018. Teknologi suplementasi sakura blok plus berbasis bahan pakan lokal untuk meningkatkan produksi susu sapi perah di kelompok ternak Sumber Mulya Kecamatan Kabawetan Kepahiang. Laporan Pengabdian pada masyarakat. Lembaga Penelitian dan Pengabdian Masyarakat. Universitas Bengkulu.

Setiadi, B. dan P. Sitorus. 1983. Penampilan Reproduksi dan Produksi Kambing Peranakan Etawah. Dalam pertemuan Ilmiah Ruminansia Kecil. Pusat Penelitian dan Pengembangan Ternak. Bogor.

Sidik, M. dan A. Muhtadi. 1992. Temulawak (Cucurma xanthorrhiza Roxb). Pengembangan dan Pemanfaatannya Obat Bahan Alam. Phytomedical,
Yayasan Pengembangan Obat Bahan Alam.

Sudono, A. dan I. K. Abdulgani. 2002. Budidaya Aneka Ternak Perah. Diktat Kuliah Jurusan Ilmu Produksi Ternak, Fakultas Peternakan. Institut Pertanian Bogor, Bogor.

Tasripin, D. S. 2009. Pengaruh pemberian ransum berimbuhan kunyit, Zn Proteinat dan $\mathrm{Cu}$ Proteinat terhadap penurunan status mastitis sub klinis pada Sapi Perah Fries Holland. Seminar nasional Teknologi Peternakan dan Veteriner.

Yusdja, Y. 2005. Kebijakan ekonomi industri agribisnis sapi perah di Indonesia. Analisis Kebijakan Pertanian. 3(3):257-268

Zuhra, C. F, J. Br. Tarigan, and H. Sihotang. 2008. Aktivitas Antioksidan Senyava Flavonoid dari Daun katu (Sauropus androgunus (L) merr). Jurnal Bilogi Sumatra. 3(1):7-10 